\title{
GEOLOGY
}

UDC 551.24(574)

Y.V.Ponomareva, orcid.org/0000-0003-1322-6773,

M.V.Ponomareva, orcid.org/0000-0001-8652-9607,

A.V.Sadchikov, orcid.org/0000-0002-6022-2073,

N.V.Zhelayeva,

orcid.org/0000-0003-3572-3578 https://doi.org/10.33271/nvngu/2021-4/005

Karaganda Technical University, Karaganda, the Republic of Kazakhstan, e-mail: evmussina1992@gmail.com

\section{A MODEL OF THE TECTONIC DEVELOPMENT OF IRTYSH SHEAR ZONE IN TERMS OF PRESENT DAY RADIOISOTOPE DATA}

Purpose. To present the model of tectonic development of the Irtysh shear zone, based on recent uranium-lead dating for zircon.

Methodology. The authors analyzed the results of studies of foreign and domestic scientists, conducted field research, sample preparation, carried out iso-tope studies using SHRIMP-2 and LA-ICP-MS technology; determined small elements by the fusion method using ICP.

Findings. Based on more than ten uranium-lead dating for zircon using the local method and the given geological and structural data, model of the Irtysh shear zone tectonic development has been proposed

Originality. A tectonic model has been developed and the age and structural relationships of the Irtysh shear zone with the Kalba-Narym zone based on uranium-lead zircon dating have been established.

Practical value. The article considers the structural and age relationships of the Irtysh crush zone which prove its formation along the deep Irtysh fault in the course of a long multi-stage tectogenesis.

Keywords: crystalline schists, ophiolite complex, tectonic evolution, green shale, dike, collision, uranium-lead datings

Introduction. The Irtysh shear zone (ISZ) divides the structures of the Rudno-Altai and Irtysh-Zaisan fold systems. It was formed along the deep Irtysh fault in the course of a long multi-stage tectogenesis. In the present day structure, the zone is a narrow linear block with the width of 15 to $30 \mathrm{~km}$. Its central part is composed of crystalline schists of high metamorphism including bodies of gabbro-diabases, plagiogranites, gneiss granites, anatectic and injection-metasomatic granitoids, along the periphery green shales. Along the Irtysh deep fault, there are boils and lenses of serpentinites of anthophyllite shales, amphibolites, basalts, diabases metamorphosed under the conditions of the greenschist facies that are fragments of the ophiolite complex.

Studying the ISZ was began in the 1930-s and with interruptions has been continued to the present day. At the same time, despite the relatively high degree of geological study, a lot of questions relating to its structure, geodynamics, metamorphism, deformations remain insufficiently studied and debatable.

The purpose of the work is to study the model of tectonic development of the Irtysh shear zone.

In the period of 1998-2012 a group of scientists of the Siberian Branch of the Russian Academy of Sciences together with foreign colleagues [1] attempted to clarify the time and significance of visco-plastic deformations for the evolution of the Kazakhstan part of the Irtysh shear zone (ISZ). The methods of investigation included: structural field studies and isotope laboratory analyses including U-Pb-7 dating by "wet"

(C) Ponomareva Y.V., Ponomareva M.V., Sadchikov A. V., Zhelayeva N. V., 2021 classical methods; $\mathrm{Ar} / \mathrm{Ar}-7$ dating; $\mathrm{Rb} / \mathrm{Sr}-1$ isochron and $\mathrm{Sm} /$ $\mathrm{Nd}-4$ dating by isotope-geochemical method with determining the model age. Based on the late Paleozoic argon-argon and uranium-lead dating, the authors distinguished two stages of metamorphism $(282 \pm 1 \mathrm{mln}$ years and $265 \pm 2$ million years) within the framework of the structure. The geodynamics of metamorphism was explained by visco-plastic deformations and many-kilometer shear components. At the same time, E. I. Patalaha, et al. (1985) showed that even under the conditions of the tenth tectonofacies, the "flowing quartz" could appear without a sign temperature gradient, and it is not possible to detect metamorphic rocks above the greenschist facies in such shear seams [2].

Surreptitiously, as a temperature gradient, the authors had in mind the presence of the gabbro-ultrabasite belt in the composition of the ISZ, since there was simply no other explanation. However, even then the Irtysh intrusive complex was considered to be early Carboniferous in connection with the presence of pebbles of some rocks of the complex in the sediments of the Katoy suite of the middle section of the Carboniferous system.

The discrepancies in this model appeared later, when teams of authors (Briggs S. M., Yin A., Manning C. E.) and (Yermolov P. V., Polyansky N. V.) published new (Caledonian) dates of $\mathrm{U}-\mathrm{Pb}$ by the local method: the Cambrian for the migratite-gneisses of Sogra and the Kurchum megablock; the Ordovician for tonalite-gneiss in the vicinity of Fu-Yun, China; late Ordovician for the distal shale on the left bank of the Sheep Stream. After these publications it became clear that the two stages of the Permian metamorphism were nothing but the latest history of the zone development, while the ancient 


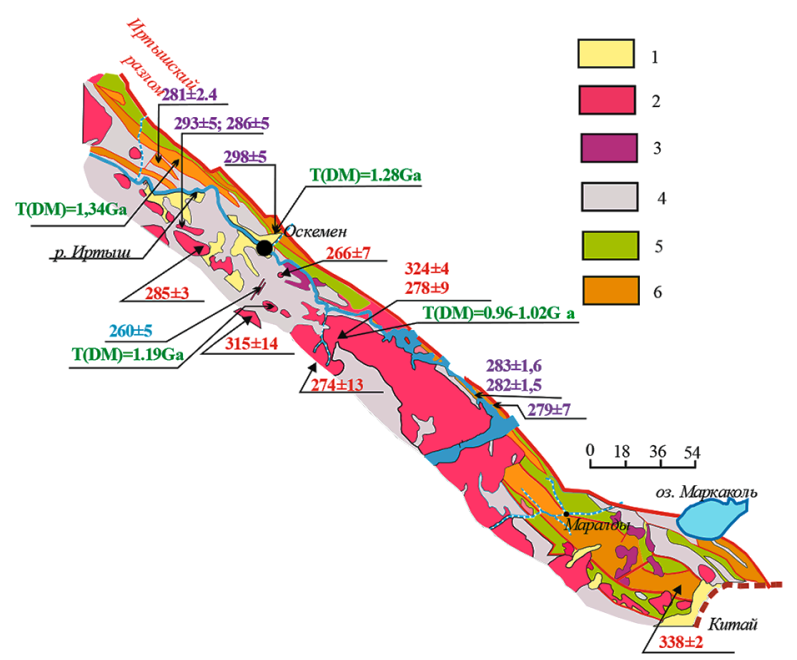

Methods of isotope studies

$324 \pm 4(\mathrm{U} / \mathrm{Pb}) 286 \pm 5(\mathrm{Ar}-\mathrm{Ar}) 260 \pm 5(\mathrm{Rb} / \mathrm{Sr}) \mathrm{T}(\mathrm{DM})=0.96-1.02 \mathrm{G} \mathrm{a}(\mathrm{Sm} / \mathrm{Nd})$

Fig. 1. 1998-2012 dating [1] in the ISZ and methods for obtaining them:

1 - the Devonian structural floor; 2 - the Kalbin batholite; 3 the Irtysh complex; 4 - the Carboniferous sedimentary pool; 5 the greenschist complex $P z_{2}\left(\right.$ ?); 6 - the late Paleozoic $\left(C_{3}-P_{1}\right)$

(Caledonian) history of the ISZ was not established by the aforementioned authors. Then two Permian stages of metamorphism were not a novelty because shortly before this,
E. G. Konnikov had summed up about $700 \mathrm{~K}$-Ar dating for the ISZ, and the average age of the ISZ rocks was the early Permian, which only confirmed the conviction that the Permian metamorphism of the zone was connected with the introduction of the Kalbin batholite. In the opinion of the abovementioned authors, the value of their studies was that two metamorphic stages accounted for left-handed global shift dislocations along the $1500 \mathrm{~km}$ zone, [3] which made the zone a very valid argument for explaining a lot of problematic issues in the evolution of the Central Asian fold belt. However, later one of the authors of this team (A. V. Travin, 2016) refused the idea of global displacement amplitudes within the ISZ estimating them by $2-3$ orders of magnitude less than previously attributed to the amplitudes (see materials of the Third Conference "Correlation ...", 2016).

In 2015 B. A. Natalyin convincingly demonstrated the existence of right-side shear deformations on the real outcrops in the ISZ. After that it became clear that while only left-sided deformations had been evaluated and right-sided ones had not been studied, it is premature to argue of the scale of displacements in the ISZ.

Ancient (Caledonian) history of tectonic evolution of the zone was clarified later after works [3]. It became clear that the Irtysh zone was originally formed in the Cambrian-Ordovician as a result of the collision of the Kazakhstan and Siberian plates under the conditions of compression and piling up of metamorphic lithoplasts in the form of a central axial horst to which other rocks joined along the accretionary mechanism including a large group of green shales. Examples of ductile (visco-plastic) folded complexes are shown in Fig. 2.

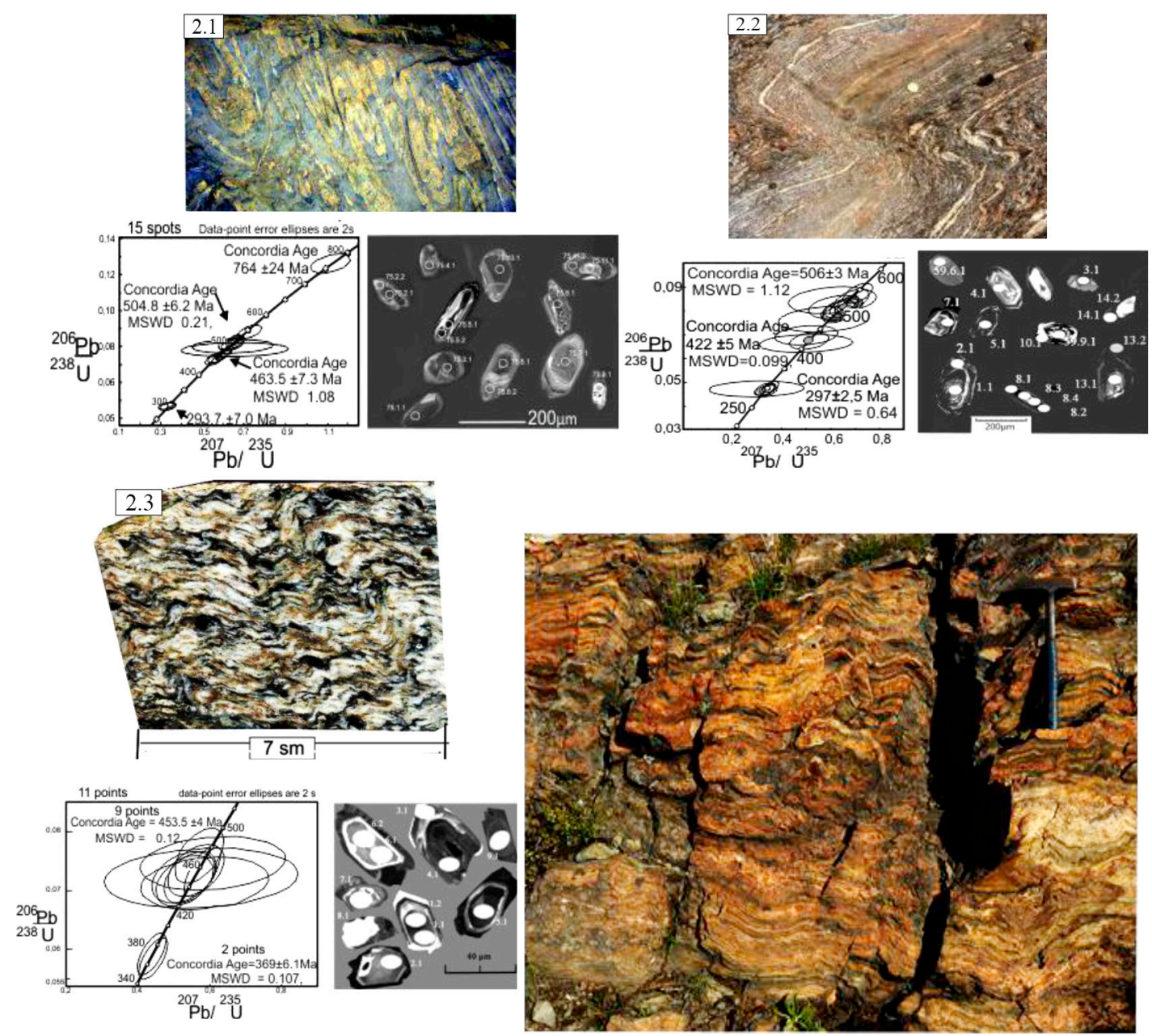

Fig. 2. Examples of visco-plastic deformations:

2.1 in-layer plicated folding; 2.2 orthogneiss-migmatite; 2.3 plicated folding in two-mica ( \pm kyanite) granite-gneisses; 2.4 plicated folding in the shale of the greenschist complex 
Early Paleozoic dating has shown that the metamorphism of the Irtysh zone is basically not local but regional, and being a regional metamorphism in general, it is associated with the endogenous energy of the Earth mantle in the form of convective and plume processes, but manifested not in the narrowly local Irtysh zone, but in general under the Zaisan paleoocean. In the Irtysh zone the Early Paleozoic metamorphic complexes (lithoplates) appeared in connection with accretion processes and are allochthonous. It can be assumed that the laying of the central metamorphic skeleton of the ISZ occurred in the Cambrian-Silurian, as it is indirectly indicated by the figures defined above as diaphthoresis, which does not exclude either one or the other.

Studying transitional plastic-brittle deformations. There are preserved macro-structures, but the infrastructure is partially or completely destroyed. In layers rich in mica, structures like boudinage or sausage are dominating (Fig. 3). The time interval separating the transient strains from plastic deformations has not been defined. Perhaps, it coincides with one of the periods indicated above the stages of diaphthoresis [4].

Studying brittle deformations and early collision. Early collision processes were manifested in the ISZ in the form of embedding dikes and small bodies oriented in the north and north-east directions. Small-amplitude shifts took place on them that led to forming ladder type dikes against the background of the former general north-western orientation. Some of them are shown in Fig. 4.

Fig. 4.1 shows the complex adamellite body (sample 94) dissecting the ancient metamorphic complex including migmatite-gneisses and plagioclase-diopside crystalline schists.

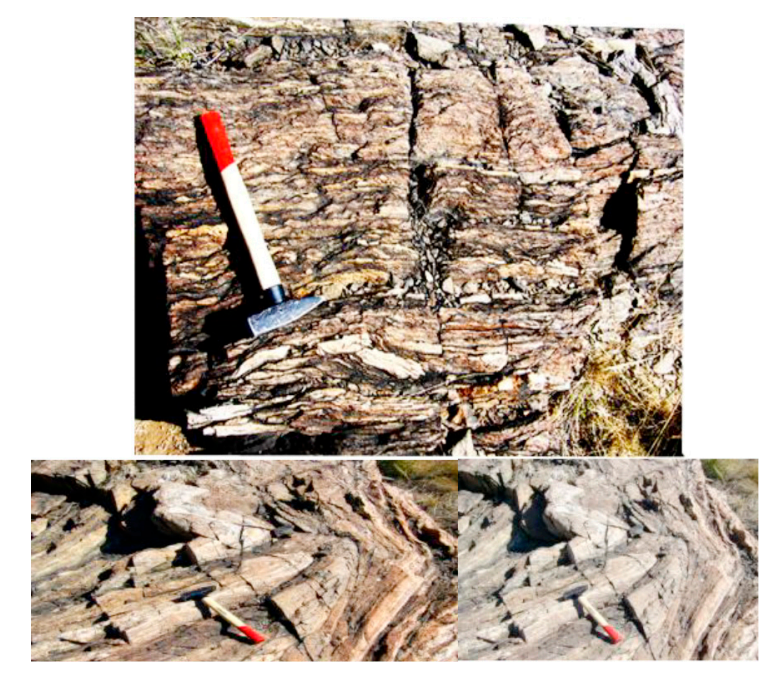

Fig. 3. Rocks at the stage of transient plastic-brittle deformations

In Fig. 4.2, there are two dikes dissecting the Early Paleozoic metamorphic complex. Of these there were selected samples for isotopy 163-1 (tonalite) and 163-2 (fine-grained aplite-like granite)

In Fig. 4.3, there is submeridional dike tonalite (sample 166) crossing the Early Paleozoic migmatite gneisses.

In Fig. 4.4, there is a table of dating for zircons from dikes and small bodies in the samples. The green shadow strip is the average duration of the appearance of fragile deformations and
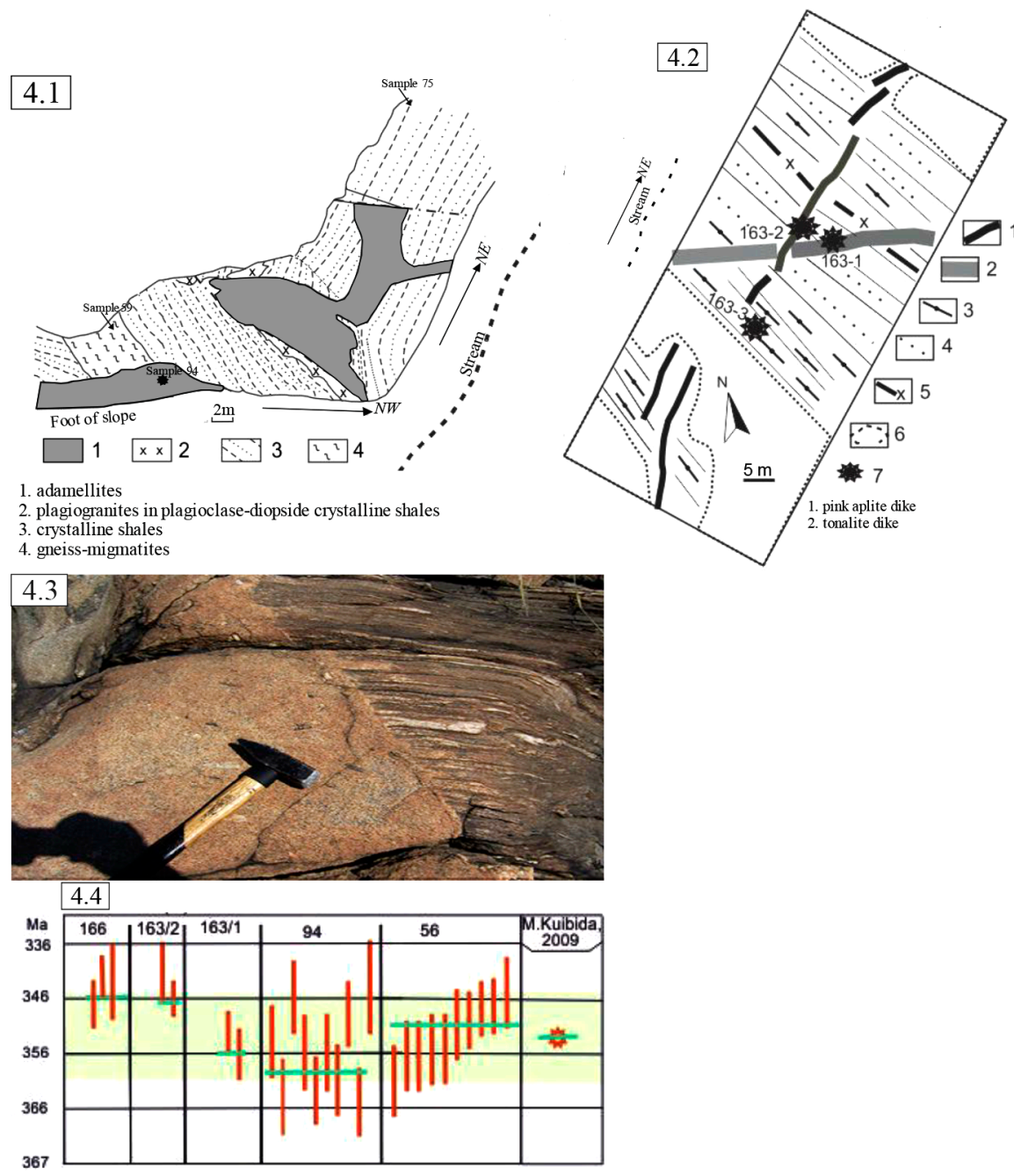

Fig. 4. Examples of ladder type dikes 
early collisions, the ranges of dating at local zircon points from the above samples, the data from the dike in the area of the Maraldy settlement on the right bank of the Kurchum river (test 56) and the dating by M. Kuibid from the plagiogranites of the Sary-Tau massif in the ISZ Kurchum block [5].

The granite-gneiss Chechek dome is a tectonic block in the ISZ bounded from the north-east and south-west by faults. From the east the block of granite gneisses is bounded by the "sickle-shaped" Surovsky massif of the gabbroids of the Irtysh complex. In the papers dealing with the ISZ much attention is paid to the Chechek gneiss dome (Fig. 5). Below there is given our version that, in a lot of respects, does not coincide with the other versions [6].

The entire dome is lined with fissures of contraction, which are usually observed in cooled granite massifs and are called cracks of separation or shrinkage cracks. The cracks mapping showed that in the center of the lithoplate the separate beds are either subhorizontal or very hollow. In the northwestern part of the dome both cracks and lithoplate joints are submerged at the angle of $25-30^{\circ}$ under the south-western edge of the Irtysh fault and under the Surovsky massif.

The entire core obtained by drilling the Talovsky (Surovsky) massif in four wells (in the process of searching for copper-nickel ores), at the request of the district geologist E. M. Yurchenko was documented and described by P. V. Yermolov. All the wells in the south-western endocontact of the Surovsky massif, under gabbroids, in different areas were exposed by shales of Takyr $\left(\mathrm{D}_{3}-\mathrm{C}_{1} t k\right)$ and Kystav-Kurchum $\left(\mathrm{D}_{2} k k\right)$ suites. Therefore, all the claims that the gneisses were located above the Surovsky massif and were genetically formed under the thermal impact of the Surovsky massif do not correspond to reality. Rather, the Surovsky massif together with the hornfels exocontact zone was tectonically pushed onto the Chechek dome that at the time ( $375 \pm 2 \mathrm{Ma})$ had already existed. It is also not confirmed that the "chechekchits" belong to the amphibolite facies of metamorphism [7].

Back in the 80 -s of the last century P. V. Yermolov wrote: 1) biotite and muscovite are abundantly present in the "chechekchits" in the absence of potassium feldspar, which is a sign of the greenschist facies of metamorphism (decomposition of biotite and formation of potassium spar is the lower boundary of the amphibolite facies); 2) granite in "chechekchits" is universally represented by the low-temperature al-

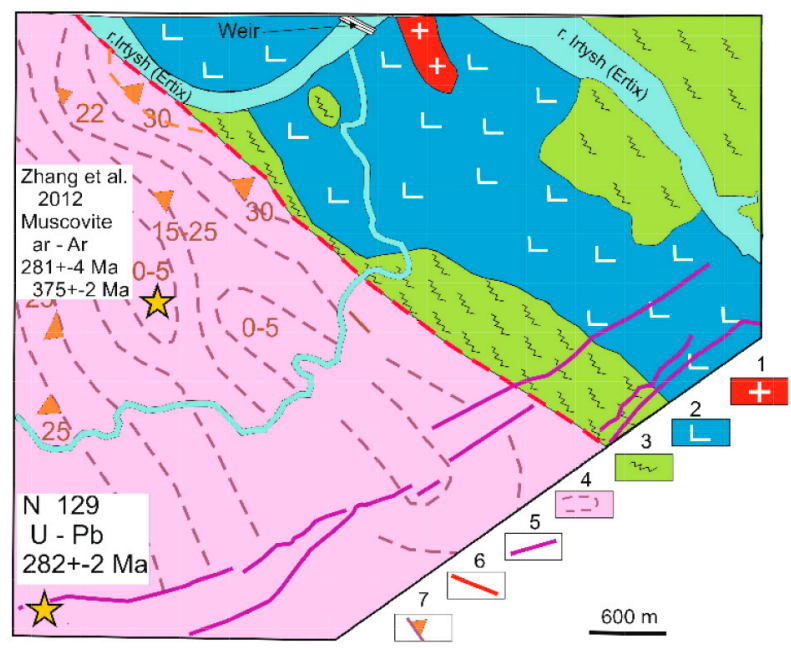

Fig. 5. A fragment of the Chechek gneiss dome on the left bank of the Irtysh river:

1 - undeformed granite; 2 - the Surovsky gabbro-peridotite massif; 3 - the green shale complex $S_{2}$, in the south-west exocontact transformed into plicated hornfels; 4 - contraction cracks in gneisses; 5 -dikes of quartz-feldspar granite-porphyries; 6 - the boundary south-western Irtysh fracture; 7 - direction and angle of incidence of contraction cracks mandine-spessartine phase, and in granite the content of the pyrope molecule is $2-3 \%$, which is also a sign of greenschist facies. In metamorphic rocks of the amphibolite facies, the pyrope content in granite is in principle determined by the medium and the crystallization temperature, usually about $10 \%$, and reaches $16-18 \%$; 3) the Chechek gneiss massif is a protrusive dome whose roots go to the gneiss basement of the Kalba-Narym zone and are not directly connected with the ISZ.

Results. Based on more than ten uranium-lead dating for [8] zircon using the local method and the given geological and structural data, the following model of the ISZ tectonic development has been proposed:

1. Formation in the Paleo-Zaisan oceanic basin in the rifttype trough that divides the axial horst structure of the Kazakhstan and the Siberian continents, which consists of allochthonous metamorphic plates of the amphibolite-granulite complex of the oceanic basement. Its age is the early Cambrian - the average Ordovician.

2. Framing the horst by the same metamorphic plates of the greenschist complex of heterogeneous origin. The mode is compression of the north-north-east direction, manifestation of plicated folding in slightly diagenetic sandy-tuff-schist rocks. The age is the Silurian-Early Devonian.

3. After relative consolidation of the axial horst structure under the conditions of continuing compression of SW-NE, transient plastic-brittle deformations took place in it that strengthened its consolidation.

4. The next stage of brittle deformations led to forming a network of discontinuous deformations and manifestation of discordant shifts in the directions: N-S; SW-NW; SSE-NNW; NW-SE, which were later filled with dikes and small bodies having similar orientation. The discordant dikes and small bodies in the Chinese part of the structure (in Fu-Yun) have the same orientation as in the north-western Kazakhstan part of the ISZ. A great variety of such shear deformations indicates their connection with differentiated movements of the foundation blocks in conditions of the entire region rising on the whole. This phase of tectonic evolution is associated with an early collision. It can be stated that early-collision processes in the ISZ took place in the range of 346-360 million years, i.e. in the late Devonian-Early Carboniferous.

5. After the appearance of early-collision deformations, the ISZ and the Kalba-Narym zone acted as a single structure (Fig. 5). In the Figure it is evident that [9] in the Chechek granite-gneiss dome two dating were obtained: $375 \pm 2$ Ma close to the range of 346-360 Ma, and $281 \pm 4 \mathrm{Ma}$ for the final collision. The same age $(282 \pm 2 \mathrm{Ma})$ was obtained for zircons from discordant dikes that cut through the unified East-Kalbinsky zone (Fig. 5) in whose structure the ISZ is included [10].

\section{References.}

1. Yermolov, P.V. (2013). Actual problems of isotope geology and metallogeny of Kazakhstan. Karaganda: ed.-Polygraph. Center of Kazakhstan-Russian University.

2. Gloriea, S., Gravea, J.De., Buslov, M.M., Zhimulev, F. I., Izmerc, A., Vandoornea, W., Ryabininb, A., ..., \& Elburga, M.A. (2011). Formation and Palaeozoic evolution of the Gorny-AltaiMongolia su-ture zone (South Siberia): zircon $\mathrm{U} / \mathrm{Pb}$ constraints on the igneous record. Gondwana Research 20, 465-484. https://doi. org/10.1016/j.gr.2011.03.003.

3. Yermolov, P.V., \& Ponomareva, Ye. V. (2019). Studying early collision and tran-sitional plastic-fragile deformations in the Irtysh shear zone structures. Materials of the International Conference "Scientific research of the SCO countries: synergy and integration”, 125-129.

4. Pak, Y. N., Ponomareva, M. V., \& Pak, D. Y. (2012) Radioisotopic $\mathrm{X}$-ray fluorescent analysis of coal's sulfur content. Coke and Chemistry, 55(8), 294-296. https://doi.org/10.3103/S1068364X12080078/. 5. Zhanga, Ch.-L., Santosh, M., Zoud, H.-B., Xu, Y.-G., Zhouf, G., Dong, Y.-G., Dinga, R.-F., \& Wang, H.-Y. (2012). Revisiting the Irtysh tectonic belt: Implications for the Paleozoic tectonic evolution of the Altai orogeny. Journal of Asian Earth Sciences, (52), 117-133. https://doi.org/10.1016/i.jseaes.2012.02.016. 
6. Glorie, S., De Grave, J., Delvaux, D., Buslov, M.M., Zhimulev, F. I., Vanhaecke, F., Elburg M.A., \& Van den haute, P. (2012). Tectonic history of the Irtysh shear zone (NE Kazakhstan): New constraints from zircon $\mathrm{U} / \mathrm{Pb}$ dating, apatite fission track dating and paleostress analyses. Journal of Asian Earth Sciences, 45, 138-149. https:// doi.org/10.1016/j.jseaes.2011.09.024.

7. Yermolov, P. V., Portnov, V. S., \& Musina, E. V. (2016). Geodynamic of Irtysh shear zone: composition and U-Pb age of metamorphic and magmatic complexes, TR-mineralization, geodynamic model. Geology and subsurface protection, (3), 1-14.

8. Dyachkov, B., Mizernaya, M., Kuzmina, O., Zimanovskaya, N., \& Oitseva, T. (2018). Tectonic and Metallogeny of East Kazakhstan // Tectonics- Problems of regional settings. p. 68. https://doi. org/10.5772/INTECHOPEN.72745

9. Dobretsov, N. L. (2011). Fundamentals of Tectonics and Geodynamics: monograph. Novosibirsk: NSU Editorial and Publishing Center.

10. Dyachkov, B., Mizernaya, M., Maiorova, N., Chernenko, Z., Maiorov, V., \& Kuzmina, O. (2011). Geotectonic Position and Metallogeny of the Greater Altai Geological Structures in the System of the Central-Asian Mobile Belt. https://doi.org/10.5772/21607.

\section{Модель тектонічного розвитку Іртишської зони зминання з урахуванням сучасних радіоізотопних даних}

\author{
К. В. Пономарьова, М. В. Пономарьова, А. В. Садчіков, \\ Н. В. Желаєва
}

Карагандинський технічний університет, м. Караганда, Республіка Казахстан, e-mail: evmussina1992@gmail.com
Мета. Надати модель тектонічного розвитку Іртишської зони зминання на підставі сучасних радіоізотопних досліджень циркону.

Методика. Авторами проведено аналіз результатів досліджень зарубіжних і вітчизняних учених, здійснене проведення польових досліджень, пробо підготовка, виконання ізотопних досліджень за технологією SHRIMP-2 i LA-ICP-MS, визначення малих елементів методом сплавлення з використанням ICP.

Результати. На основі більш ніж десяти уран-свинцевих датувань по циркону локальним методом і наведених геологічних і структурних даних авторами була запропонована модель тектонічного розвитку Іртишської зони зминання.

Наукова новизна. Розроблена тектонічна модель і встановлені вікові та структурні співвідношення Іртишської зони зминання 3 Калба-Наримською зоною на основі уран-свинцевих датувань по циркону.

Практична значимість. Розглянуті структурні й вікові співвідношення Іртишської зони зминання, що підтверджують iї формування вздовж глибинного Іртишського розлому у процесі тривалого багатоетапного тектогенезу.

Ключові слова: кристалічні сланці, офіолітовий комплекс, тектонічна еволюція, зелені сланці, дайка, колізія, уран-свинцеві датування

Recommended for publication by V.S. Portnov, Doctor of Technical Sciences. The manuscript was submitted 11.01.21. 